\title{
A Model for Cocoa Farmers' Group Strengthening in the Regency of Kolaka Timur, Southeast Sulawesi, Indonesia
}

\author{
Putu Arimbawa, Hartina Batoa, Iskandar Iskandar, Muhammad Aswar Limi* \\ Department of Agribusiness, Faculty of Agriculture, University of Halu Oleo, Kendari, Indonesia \\ Email address: \\ ariembawa_kdi@yahoo.com (P. Arimbawa), hartina_batoa@yahoo.com (H. Batoa), sicky@yahoo.com (I. Iskandar), \\ aswar_agribusiness@yahoo.com (M. A. Limi) \\ ${ }^{*}$ Corresponding author
}

\section{To cite this article:}

Putu Arimbawa, Hartina Batoa, Iskandar Iskandar, Muhammad Aswar Limi. A Model for Cocoa Farmers' Group Strengthening in the Regency of Kolaka Timur, Southeast Sulawesi, Indonesia. Agriculture, Forestry and Fisheries. Vol. 5, No. 6, 2016 , pp. $266-271$. doi: 10.11648/j.aff.20160506.18

Received: October 26, 2016; Accepted: November 18, 2016; Published: December 29, 2016

\begin{abstract}
The existence of cocoa farmers' groups is expected to play a role in improving the cocoa farmers' prosperity. The objectives of the study were (1) to formulate strategies for strengthening cocoa farmers' groups in order to improve the cocoa farmers' prosperity, and (2) to analyze a strengthening model for sustainable cocoa farmers' groups. The study was conducted in the Village of Mondoke, District of Lambandia, Regency of KolakaTimur. The samples were members of two purposivelychosen farmers' groups each of which consisted of 20 members, therefore, the total number of samples was 40 farmers. The data were analyzed descriptively and by using SWOT analysis according to the in-depth interview and focus group discussion. The results showed that (1) strategies for strengthening cocoa farmers' groups were (a) by developing groups into joint ventures in supporting their cocoa agribusiness; (b) by creating collaborations and partnerships with third parties in improving yield, quality, and marketing; (c) by playing significant roles in providing training and guidance to farmers; and (d) by improving cohesiveness of farmers' groups via reliable leaderships, and (2) farmers' group strengthening model could be done through social empowerment approach, such as intensified trainings of cocoa farming, farmers' group capacity improvement, social capital increase, and inter-farmers' group network establishment.
\end{abstract}

Keywords: Farmers' Group, Strengthening Model, Cocoa Farmers

\section{Introduction}

The regency of Kolaka Timur is one of the cocoa producing areas in Southeast Sulawesi. The region can produce $40,122 \mathrm{t}$ cocoa beans $\mathrm{y}^{-1}$ with a total smallholder cocoa plantations of 94,000 ha. Based on the data, their productivity is still relatively low $\left(0.4 \mathrm{t} \mathrm{ha}^{-1} \mathrm{y}^{-1}\right.$ on average $)$. The low productivity is brought about by that the cocoa plants are already old ( $>20$ years old), post-harvest and marketing of the cocoa beans have yet to be carried out so well that the cocoa bean quality is still low [1]. In addition to the production and post harvest problems, another problem is correlated to institutions [2]. Institution revitalization requires flexible strategies and it should meet formal and informal institution elements. The strengthening of local institutions leads to the achievement of positive effects which are in agreement with the local development. One of the institution revitalization components is social participation [3].

Based on these conditions, cocoa farmers' groups need empowerment. The roles of the groups can be seen from the improvement of farmers' skills in farming [4]. Cocoa farmers' group empowerment can be seen as guidance for the farmers in meeting production inputs and product marketing in order for them to be able to earn an increased income. The objectives of the study were (1) to formulate strategies for strengthening cocoa farmers' groups in order to improve the cocoa farmers' prosperity, and (2) to analyze a strengthening model for sustainable cocoa farmers' groups.

\section{Methods}

The study was conducted in the Village of Mondoke, 
District of Lambandia, Regency of Kolaka Timur, Southeast Sulawesi, Indonesia. Such an area was chosen for the study site because the majority of its population were cocoa farmers. The study objects were farmers belonging to cocoa farmers' groups. Two farmers' groups were purposively selected as samples. Each group consisted of 20 farmers, therefore, the number of samples was totally 40 cocoa farmers. The data were analyzed descriptively and by using SWOT analysis according to the in-depth interview and focus group discussion.

\section{Results and Discussion}

\subsection{Cocoa Farmers' Group Activities}

Farmers' group activities such as group mentoring can be done by providing trainings as to cocoa farming to the members of the farmers' groups. The study showed that most members $(86 \%)$ had attended trainings facilitated by the groups. The trainings that had been attended were about cocoa farming techniques and management.

In addition, increasing farm capital should also be done within the group. Capital plays important roles in acquiring the inputs for cocoa production. The problems faced in the development of particularly small scale farmers are poor capital structure and limited access to a capital source [5]. The study showed that $50 \%$ of the farmers had used a cooperative as a capital source for their cocoa production, some used bank loan, and some used their own capital. The cocoa farmers' groups had owned a capital institution in a form of a cooperative. The members of the cooperative could put savings on and request for a loan from the cooperative. In order to be accepted as a member of the cooperative, there were some conditions to be met including being a member of a farmers' group and residing in the village. With this system, the cooperative keeps developing in term of the number of members and the amount of capital. The existence of capital increase in a group could boost collaboration among members. The collaboration among members in the farmers' groups mostly occurred during plant maintenance such as plant pruning and rorak (small blocked ditches) building, while the collaboration intra group was mostly done during farm road maintenance.

\subsection{Strategies for Cocoa Farmers' Group Strengthening}

Cocoa Farmers' Group Strengthening are strategies that can be applied for cocoa farmers in their attempt to improve their cocoa agribusiness. Strategies for Cocoa Farmers' Group Strengthening were analyzed with SWOT, an approach to make any strategy decision via formulating a matrix of IFAS (Internal Strategic Factors Analysis Summary) and EFAS (External Strategic Factors Analysis Summary).

\subsubsection{Internal Factors}

Internal factors consisted of strength and weakness factors that affected cocoa agribusiness. To assess the strength and weakness levels, the elements of the strength and weakness factors were weighed and rated as scores of their effect on the farmers' groups useful for making strategic decisions. The strength factors were defined as the potential owned by the farmers who had been members of the cocoa farmers' groups and by the groups per se that could support the group empowerment in the cocoa agribusiness. The strength factors included the farmers group members were within the productive ages, land resources were supporting (the farms were self-owned and the sizes were relatively large), trust level among farmers and group managements was high, motivation to grow cocoa was high, knowledge and skills in cocoa production were good.

The weakness factors were defined as the farmers' and their group weaknesses that could impair cocoa agribusiness in the future. The weakness factors included that the cocoa plants were mostly within unproductive ages, farmers' capital was relatively small, group activities were unprogrammed including the absence of routine group meetings, no clear group regulations including the absence of how to elect the group heads, no self owned farmers' groups office/headquarter, most farmers did not know their group goals, and farmers' educational levels were inadequate. [6] reported that there was a strong correlation between cocoa production and famers' socio-economy. Farmer's and cocoa plant's age, farm area, and farmer's income also had a strong positive correlation, while family size and farming experience showed a weak positive correlation.

\subsubsection{External Factors}

External factors consisted of opportunities and threats that affected the development of the cocoa agribusiness. The opportunities were defined as the potentials that could be used by the farmers and their groups for supporting the development of cocoa production in the future. Opportunity factors included that demand for cocoa beans was high, the existence of department of plantations in a form of cocoa production programs, the existence of trainings in cocoa farming, the existence of extension program in cocoa farming, the existence of institutions providing loans, and the existence of access to product marketing.

The threats were defined as factors that could impair or threaten the farmers' group strengthening in the development of cocoa production in the future. The threat factors included pest and disease invasions on cocoa plants, the absence of farmers' groups capacity building improvement, high price inputs and their low availability, fluctuating cocoa bean price, and the presence of another commodity (i.e. palm oil plants) between cocoa plant rows.

\subsubsection{SWOT Matrix of Strategies for Cocoa Agribusiness Development}

SWOT matrix is a tool used to determine alternative strategies suitable for the farmers in strengthening cocoa farmers' groups. Such a matrix was formulated based on the analysis of internal and external factors consisting of strengths, weaknesses, opportunities, and threats. The matrix is presented in Table 1. 
Table 1. Matrix of SWOT for Determining strategies for farmers' group empowerment in Cocoa agribusiness in the Regency of Kolaka Timur.

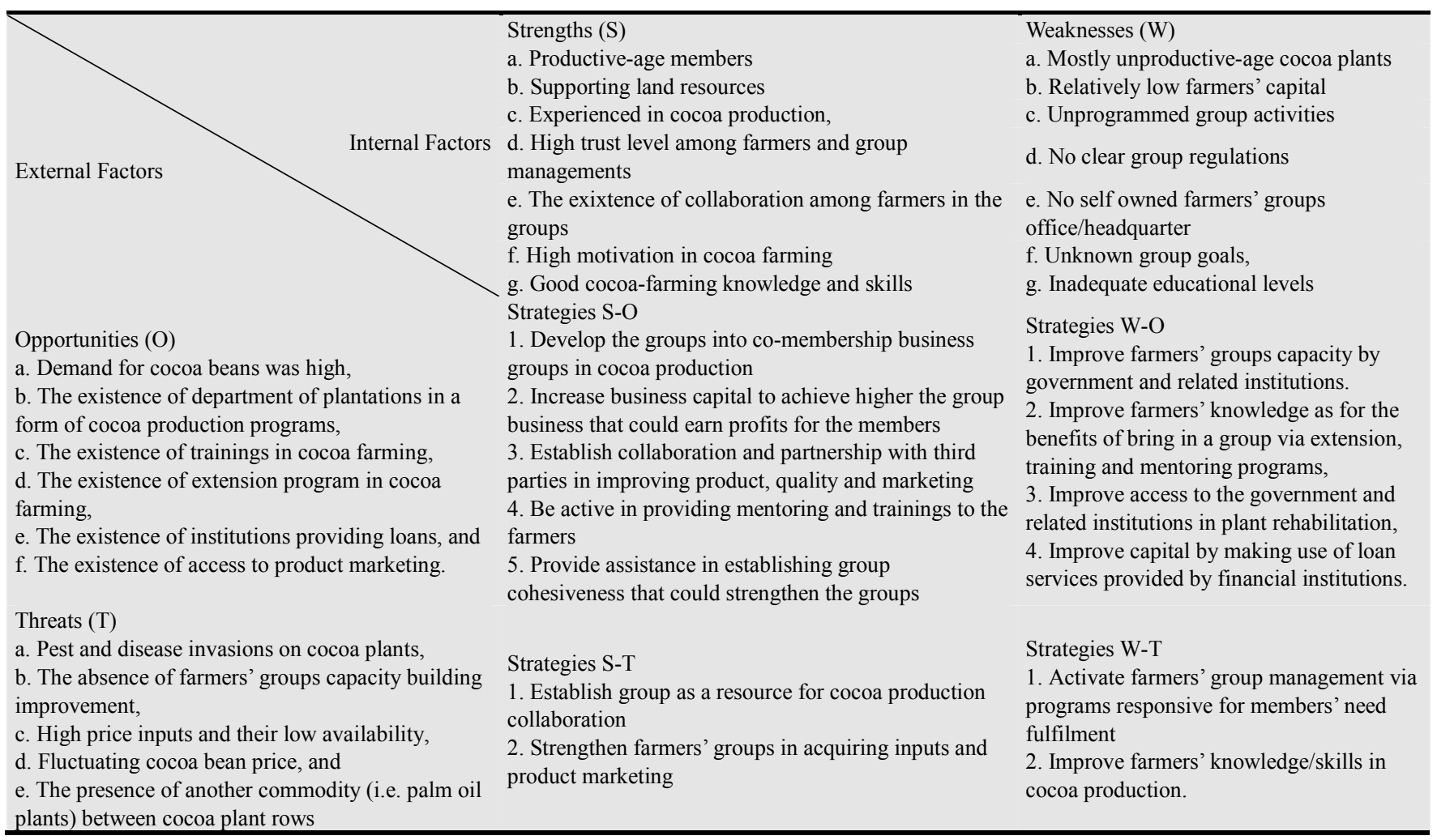

Based on the SWOT matrix, a SWOT map was built to indicate that the group strengthening strategies in the Regency of Kolaka Timur were focused on strategy S-O. In spite of that, there was always a probability to conduct other strategies for supporting and accelerating the development of cocoa production in the future. As seen in the SWOT matrix, the strategies S-O strengthening cocoa farmers' groups could be done via (1) developing the groups into co-membership business groups in cocoa production, (2) increasing business capital to achieve higher the group business that could earn profits for the members, (3) establishing collaboration and partnership with third parties in improving product, quality and marketing, (4) being active in providing mentoring and trainings to the farmers, and (5) providing assistance in establishing group cohesiveness that could strengthen the groups.

\subsection{Strengthening Institution Model for Cocoa Farmers' Groups}

To strengthen the institution model for cocoa farmers' groups could be done through farmer empowerment, improved access to capital, increase in farmers' group capacity, increase in farmers' group social capital, and development of business network and partnerships.

\subsubsection{Farmer Empowerment}

Some approaches for farmer empowerment that can be done to succeed in cocoa production include improvement of human resources (e.g. cocoa farmers), increased access to capital, and establishment of partnership or network among farmers' groups.

Human resources can be improved by providing education and trainings. The survey showed that $40 \%$ of the farmers only graduated from elementary school and $35 \%$ of the farmers did not graduate from elementary school and some of which did not even attend any formal education. Their low education levels indicate that they require a program to improve their knowledge that can be done via providing trainings or short courses. The survey also showed that $85 \%$ of the farmers once attended trainings facilitated by the farmers' groups. Such a condition also indicates that some of them $(15 \%)$ never attended any training at all. There are four highest ranks of training topics including product processing, marketing, plant management and maintenance, and sanitation. The training topics are effective if done in groups [7]. Trainings carried out in groups could improve technical competition and farmers' social management [8]. Cocoa farmers' capital increase and income could be achieved through training in the area of farming techniques, the use of simple soil analysis tool to analyze soil fertility, handling of diseased and mummified pods removed from the farms, and appropriate methods of soil replenishment to encourage better yield $[9,10]$. The trainings were not relatively institutional based, therefore, the lack of such an approach should be improved to increase their cocoa bean production [11]. Training and visit innovation had an impact on farming area and farmer's income [12].

The establishment of farmers' groups is expected to be institutions that provide capital for cocoa production. The survey showed that $50 \%$ of the farmers had benefited from 
the existence of the groups because of the capital the groups provided (in a form of loan) to the farmers through the group's cooperative. In order for the farmers to optimally use the loan provided by the cooperative, it is required that the group management socialize it to the members. Besides, the management should be so creative that the capital can be well used by the members of the groups for cocoa production. According to Anoraga et al. (2002) in [13], capital acquirement could be achieved through bank loans, non-bank loans, venture capital, loan from state-owned companies, grants, and so forth.

In addition to the business capital, the improvement of farmers' knowledge or skills could be done by building partnership network among the farmers. This can improve the farmers' knowledge through programs such as discussions and collaborations in farming management. Based on the survey, some partnership networks had been developed, for instance, through the establishment of team works among the farmers.

\subsubsection{Improving Farmers' Group Capacity}

An improved Farmers' Group Capacity could improve the farmers' capability in agriculture, yield quality, and marketing, therefore, they possess a strong bargaining power in cocoa farming management.

The existence of cocoa farmers' groups has benefited the cocoa farmers. However, there are still a lot of room for improvement that can be done in order for it to become a problem-solving institution for the cocoa farmers. According to [14], group activities that lead to the group's and its members' objectives are one of the group's characteristics that could develop the group's dynamics. Improving group roles hopefully could improve farmers' skills in agriculture, yield quality, and marketing, therefore, they possess a strong bargaining power in cocoa farming management. An improved cocoa farmers' group capacity could be achieved by (a) improving the group management capacity in managing the groups, (b) improving farmers' group leadership in boosting farmers' trust, and (c) increasing the coordination among farmers and groups in a region. In addition, group capacity strengthening can be done by applying the group's regulation and by acquiring group's supporting facilities. The priority solutions in strengthening farmers' group institution are institutional aspects including function and role optimization according to the group's rules [15].

\subsubsection{Strengthening Cocoa Farmers' Group Social Capital}

Social capital can be strengthened by the members and the management of farmers' groups. The social capital can be achieved by establishing network, trust, and togetherness among cocoa farmers.

The establishment of networks among farmers can be done based on total requirement for any business activity, such as requirement for seeds, fertilizers, pesticides and other social activities. The growth of such a network among the farmers would improve farmers' participation in every group activity. The presence of a farmers' group could be a medium for facilitating cocoa farmers to establish a network among the farmers especially with regard to production, harvest and post harvest, and product marketing. Building farmers' groups should be focused on strengthening vertical bonds, such as, post harvest handling and product processing, ingroup marketing, and making partnership in agribusiness [16]. Such a network would be established if trust among farmers exists. Trust is measured in a form of the level of faith in others' words, agreements, and actions consistently when the establishment of relationship among individuals and groups (organizations) in a society. The level of one's trust can be seen from the level of one's commitment, honesty, and responsibility. The survey showed that the level of the cocoa farmers' trust in the farmers' group was relatively high. To establish trust from the farmers could be done by intensifying communication forums between the management and farmers and among the farmers themselves. The study conducted by [17] revealed that the elements of social capitalthat could support cocoa farmer strengthening were values of brotherhood and cooperativeness, trust, harmony, life style, competition and social network.

The existence of network among the farmers would enable togetherness to emerge. The survey showed that the farmers' togetherness was relatively high. This could be seen from relatively high farmers' participation in every group activity in which the farmers communicate any group activity from one to another. Therefore, strengthening farmers' groups should pay attention at least to existing social values in forms of honesty, norm enforcement, transparency, competency, togetherness, trust and faith that should be owned and maintained by the groups when playing a role as a medium either socially or economically.

\subsubsection{Developing Farming Network and Partnership}

Developing partnership network is required to accelerate the achievement of any institutional objective. No institution can survive and grow in the absence of partnership network among the existing groups. Developing partnership network, particularly for farmers' groups, becomes essential because the resulting products are closely related to the world-wide marketing conditions. Therefore, such a partnership is required to ensure price stability of the products. Cocoa is one of South-east Sulawesi's main agricultural commodities. The survey showed that some of its cocoa production, such as acquiring fertilizer and capital, had been fulfilled by the groups. The post harvest and marketing processes tended to be done by each farmer, therefore, the selling price for the cocoa beans was highly determined by buyers. By that, the farmers did not have enough bargaining power. The farmers' groups had not been capable of purchasing members' cocoa beans because of the incapability of managing their members' products as a result of the lack of managerial skill of the groups' management and the lack of groups' infrastructures. In addition, farmers' groups had not had any collaboration with any marketing institution. Partnership in marketing cocoa beans is built to ensure the steady flow and the achievement of particular volume of cocoa bean supply 
demanded by an exporter and market certainty for famers [18].

Developing partnership networks with third parties will succeed if communication networks have been developed among groups in the village/district levels. There are 11 institutions actively involved in increasing cocoa production including (1) Indonesian Coffee and Cocoa Research Institute (ICCRI), (2) Gardens Management Coordination Forum (FKMK), (3) Indonesian Cocoa Association (ASKINDO), (4) Indonesian Cocoa Farmers Association (APKI), (5) Indonesian Cocoa Industry Association (AIKI), (6) Provincial Office for Plantation, (7) Financial Institutions/Banks, (8) Marketing Agencies, (9) Local Office for Forestry and Plantation, (10) Extension Service Officer in District level, and (11) Joined Farmers Group (Gapoktan) [11]. All stakeholders (Plant Breeders, Agronomists, Post Harvest Technologists, Ministry of Food and Agriculture (MOFA) and Farmers) should be actively involved in the development of farming technologies [19]. The establishment of inter-group partnership networks will boost the trust from business partners (e.g. firms, production input suppliers, and banking institutions) about the potential of the cocoa farmers' groups.

\section{Conclussion}

Based on the results and discussion, it can be concluded that (1) strategies for strengthening cocoa farmers' groups were done by (a) developing groups into joint ventures in supporting their cocoa agribusiness, (b) creating collaborations and partnerships with third parties in improving yield, quality, and marketing, (c) playing significant roles in providing training and guidance to farmers, and (d) improving cohesiveness of farmers' groups via reliable leaderships, and (2) farmers' group strengthening model could be done through social empowerment approach, farmers' group capacity improvement, social capital increase, and inter-farmers' group network establishment.

\section{Acknowledgement}

We, authors, would like to send our gratitude and appreciation to the Ministry of Research, Technology and Higher Education of the Republic of Indonesia for providing the grant through the Competency Grant issued in 2016.

\section{References}

[1] Disbun Kolaka Timur. 2015. Pengembangan Komoditi Kakao di Kolaka Timur. Disbun Koltim.

[2] Iqbal M. dan Dalimi A. 2006. Kebijakan Pengembangan Agribisnis Kakao Melalui Primatani: Kasus Kabupaten Luwu, Provinsi Sulawesi Selatan. Analisis Kebijakan Pertanian, Vol. 4 Nomor 1: p45-52.

[3] Suradisastra K. 2006. Revitalisasi Kelembagaan untuk Percepatan pembangunan Sektor Pertanian dalam Otonomi
Daerah. Analisis Kebijakan Pertanian, Vol. 4. Nomor 4: p308313.

[4] Arimbawa P. dan Sidu D. 2007. Peran Kelompok untuk Meningkatkan Kemampuan Anggota dalam Inovasi Teknologi Program HKm di Kabupaten Konawe Selatan, Sulawesi Tenggara. Majalah Ilmiah Agriplus, Vol 17. Nomor 01 Januari 2007: $p 52-63$.

[5] Almasdi Syahza dan Suarman. 2013. Strategi Pengembangan Daerah Tertinggal dalam Upaya Percepatan Pembangunan Ekonomi Pedesaan. Jurnal Ekonomi Pembangunan. Vol 14, No 1 Juni 2013. P126-139.

[6] Adefila J. O. 2013. Spatial Effects of Cocoa Production on Rural Economy in Idanre-Ifedore Area, Ondo State of Nigeria. Asian Economic and Social Society. Volume 3 No. 2 February 2013. p56-66.

[7] Muhammad Arsyad. 2013. Penguatan Kelembagaan Menuju Kesejahtraan Petani: Pengalaman dari Kondisi Terkini Petani Kakao di Sulawesi. Simposium Nasional Ekonomi Kakao. Prosiding. Perhimpuanan Ekonomi Pertanian dan Fakultas Pertanian UHO. Kendari. P217-228.

[8] Batoa Hartina dan Arimbawa P., 2012. Analisis Kebutuhan Pelatihan Penyuluh Pertanian. Majalah Ilmiah Agriplus. Vol 12 Nomor 02 Mei: p148-154.

[9] Philippe Pe delahore. 2014. Farmers accumulation strategies and agroforestry systems intensification: the example of cocoa in the central region of Cameroon over the 1910-2010 period. Agroforest Syst (2014) 88: 1157-1166.

[10] Adeogun, S. O., Fapojuwo, E. O., Oyeyinka, R. A., Adamu, C. O. And Abiona, B. J. 2013. Training Needs Assessment Of Cocoa Farmers Association Members On Soil Management Techniques In Cross River State Of Nigeria. Ethiopian Journal of Environmental Studies and Management. Vol. 6 No. 5 2013. p551-561.

[11] Nuddin, A., S. Yusuf, N. M. Viantika S., 2015. An Alternative Model of Cocoa Production Institution: A Solution in Facing ASEAN Economic Community. International Journal of Agriculture System. Hasanuddin University. Makassar, South Sulawesi, Indonesia. Volume 3 Issue 2, Desember 2015: p143156.

[12] Oladipupo, A. M., O. F Egbenayabuwa, Caroline Sede. 2014. Effect of $\mathrm{T} \& \mathrm{~V}$ innovation on income and farmers performance in Edo State Nigeria. American Journal of Agriculture and Forestry. 2014; 2 (4): 159-167.

[13] Elviati. 2008. Analisis Pemupukan Modal untuk Pengembangan Usaha pada Industri Kecil Makanan Spesifik Kota Payakumbuh. Jurnal Penelitian Lumbung. Vol. 7, No. 2: p1072-1082.

[14] Surmardjo. 2012. Kelembagaan Masyarakat Tani. Merevolusi Revolusi Hijau. Pemikiran Guru Besar IPB (Buku III). Prosiding. Penyunting Roedhy Purwanto, et al.. p677-691.

[15] Santoso, P. B., dan Darwanto, 2015. Strategy for Strengthening Farmer Groups by Institutional Strengthening. Jurnal Ekonomi Pembangunan. Vol 16, No 1 Juni 2015. p33-45.

[16] Saptana, Wahyuni S., dan Sahat M. Pasaribu. 2013. Strategi Percepatan Transformasi Kelembagaan Gapoktan dan Lembaga Keungan Mikro Agribisnis dalam Memperkuat Ekonomi di Perdesaan. Jurnal Manajemen dan Agribisnis. Vol. No. 1, Maret 2013: p40-49. 
[17] La Ola T., dan Arimbawa P., 2009. Penguatan Modal Sosial Untuk Pemberdayaan Masyarakat Pedesaan Dalam Berusahatani Kakao: Studi Kasus di Desa Peoho Ex Proyek Perkebunan dengan Pola PIR Kabupaten Kolaka. Majalah Ilmiah Agriplus, Vol 19. Nomor 01: p19-25.

[18] Iswandi, M., 2013. Kelembagaan Agribisnis Kakao. Simposium Nasional Ekonomi Kakao. Prosiding.
Perhimpuanan Ekonomi Pertanian dan Fakultas Pertanian UHO. Kendari. P273-280.

[19] Emmanuel Asiedu-Darko. 2014. Farmers' perception on agricultural technologies a case of some improved crop varieties in Ghana. Agriculture, Forestry and Fisheries. Vol. 3, No. 1, 2014, pp. 13-16. 